\title{
"LA VRAI MORALE SE MOQUE DE LA MORALE”: QUESTÕES ÉTICAS EM PASCAL
}

\author{
Telma de Souza Birchal*
}

RESUMO Em Pascal encontramos um duplo registro da questão moral: por um lado, o autor dos Pensées dirige uma dura crítica aos ideais morais da filosofia, especialmente aos do estoicismo; por outro, ele afirma uma "verdadeira moral" que "zomba da moral". A análise desse duplo registro será feita a partir de quatro contextos encontrados nos Pensamentos:

1- O contexto epistemológico da diferença entre espírito geométrico e espírito de finesse, ao qual se remetem os termos correlatos "moral do espírito" e "moral do julgamento";

2- O contexto antropológico da "desproporção do homem" e da virtude como meio-termo;

3- O contexto antropológico - teológico da miséria e da grandeza do homem

4- O contexto metafísico-teológico da teoria das "três ordens de coisas”.

A "verdadeira moral" constitui-se, afinal, por dois movimentos: no primeiro, a moral pascaliana é simplesmente naturalista e compartilha do espírito mecanicista do seu século. Em seu segundo movimento, ela é teológica e constitui-se essencialmente como uma hermenêutica do desejo.

ABSTRACT We find in Pascal a double approach to the moral issue. On the one hand the author of the Pensées strongly criticizes the moral ideals of philosophy, in particular those of Stoicism but, on the other, he claims

* Departamento de Filosofia/UFMG.

KRITERION, Belo Horizonte, $\mathrm{n}^{0}$ 106, Dez/2002, p.60-76 
that there is a "true morals" which "mocks of morals". We here analyze this double approach from the point of view of four contexts exhibited in the Pensées:

1- The epistemological context that distinguishes the "esprit de géométrie" and the "esprit de finesse" which points, respectively, to a "moral of the 'esprit"" and to a "moral of judgment".

2- The anthropological context of the "disproportion of men" and of virtue as mean

3- The anthropological-theological context of the misery and greatness of man.

4- The metaphysical-theological context of the theory of the "three orders of things".

The "true morals" is construed in two movements. In the first, Pascal's morals is naturalistic and shares the mechanism of his time. In the second, it is theological and emerges essentially as an hermeneutics of desire.

Palavras-chave Pascal, moral, ética, teologia, antropologia, desejo.

\section{Introdução: a moral como problema}

O presente trabalho originou-se da seguinte pergunta: qual o estatuto da "moral" no pensamento de Pascal, ou seja, há em seu pensamento o reconhecimento de uma esfera propriamente moral? Poderá ela subsistir como esfera autônoma ou mesmo relativamente autônoma, cercada que está, por um lado, pela doutrina da queda, que tira o homem do horizonte do bem - "nós somos incapazes do verdadeiro e do bem" $\left(\mathrm{La} \mathrm{28/436)}{ }^{1}\right.$ — e, por outro, pelas exigências da caridade cristã, que são um além da moral: "ninguém é feliz como um verdadeiro cristão, nem razoável, nem virtuoso, nem amável" (La $357 / 541)$ ?

Sem dúvida, a moral é um problema para o autor dos Pensamentos, e especificamente a moral da tradição filosófica, que afirma as virtudes como excelências. Os paradigmas morais que nos chegam da filosofia aristotélica ou estóica, ao serem atravessados pelo crivo pascaliano, deixam transparecer contradições onde tudo parecia simples e sólido. Pascal retoma dos Ensaios de Montaigne a reflexão sobre a diversidade dos costumes e das crenças, que

1 As citações dos Pensées apresentam em primeiro lugar a numeração da edição de Louis Lafuma (PASCAL, Oeuvres Complètes, 1963), precedidas da indicação La. Depois da barra vem a numeração da edição Brunschvicg, seguida pela tradução para o português de Sérgio Milliet, Editora Abril Cultural, 1973. 
levanta suspeitas sobre o nosso conhecimento do bem, e a crítica à idéia do homem como ser racional, que ataca sua suposta superioridade. A "Apologia de Raymond Sebond" já havia acentuado a forte inserção da natureza nas ditas "faculdades superiores" do homem, quer dizer, a presença do corpo e suas exigências, dos interesses, da imaginação e do hábito no cerne mesmo da razão e da vontade. ${ }^{2}$ Também os Pensamentos humilham a razão, ao mostrar, por exemplo, que a imaginação é a "rainha" que "dispõe de tudo": faz a beleza, a justiça e a felicidade que é o todo do mundo" (La 44/82). ${ }^{3}$ Com os céticos, Pascal afirma a "miséria do homem", sua incapacidade de conhecer a verdade e o bem, dada a presença das potências enganadoras, que são afinal paixões, no núcleo da razão.

Outro ponto da ética tradicional, a distinção hierárquica dos tipos de homens, em especial a afirmação de uma real diferença entre a vida dedicada aos prazeres do corpo e a vida dedicada ao espírito (conhecimento ou sabedoria) são parâmetros confundidos pela "vertiginosa metafísica de Pascal" e suas "oposições súbitas do pensamento", suas "surpresas constantes por meio das quais ele passa de uma ordem de coisas à ordem contrária”, para usar os termos de Paul Bénichou em seu clássico estudo sobre as morais do século XVII. ${ }^{4} \mathrm{E}$, para continuar com Bénichou, citemos sua conclusão sobre a moral jansenista como lugar da "demolição do herói": "Todo o pensamento jansenista aparece como um empreendimento dirigido contra o idealismo moral (...) e só concede realidade a uma humanidade sem glória e sem virtude". Pois a virtude engana, bastando para isto voltarmos nossa atenção para os meandros da alma humana, exercício no qual Pascal é um mestre. Como falar em moral, de uma pretensão ao domínio de si mesmo, quando, sempre e inapelavelmente, o homem é "escravo do deleite", seja ele da carne ou do espírito?" Como falar em moral, quando, nesta vida, não se tira o pé da natureza?

A questão estaria encerrada e não haveria propriamente problema da moral em Pascal se a redução do homem aos instintos e à natureza fosse o único aspecto de seu pensamento. No entanto, a moral continua como pro-

2 As menores coisas do mundo podem alterar nosso julgamento, lemos em Montaigne, como em Pascal. Ver Ensaios, II, 12, p. 564 (Ed. Pierre Villey) e La 48/366.

3 "A imaginação amplia os pequenos objetos até encher-nos a alma com eles, em uma avaliação fantasista; e numa insolência temerária diminui os grandes e os reduz à sua medida, como ao falar de Deus" (La 531/85). Da mesma forma o "irracional" interfere na vontade, pois nossas "escolhas" são na verdade determinadas pelo acaso, o ambiente, os preconceitos (ver La 35/117 e 634/97). Sobre a primazia das impressões, Pascal escreve: "M. Roannez dizia: 'As razões me vêm depois, mas antes a coisa me agrada ou me choca sem que eu saiba a razão, e, no entanto, choca-me por esta razão que só descubro a seguir'. Não creio que a coisa choca pelas razões que se descobrem depois e sim que só se encontram essas razões porque a coisa choca" (La 983/276).

4 BÉNICHOU, 1948, p. 119.

5 PASCAL. Escritos sobre a Graça, p. 332 (Ed. Lafuma). Voltaremos especialmente a este ponto. 
blema, não é dissolvida num "para aquém do bem e do mal"; o discurso de Pascal não abdica nunca de falar deles - incognoscível um, onipresente o outro - , porque o homem vive sempre no horizonte desta distinção. $\mathrm{O}$ fragmento que nos serve de ponto de partida - "a verdadeira moral zomba da moral" - indica, como veremos, uma outra moral para além da moral dos filósofos. Se a "zombaria" no Entretien e nos Pensamentos atinge sobretudo as pretensões dos virtuosos estóicos, há lugar também, no autor das Provinciais, de se zombar da ausência de moral na casuística dos jesuítas. Ainda nos Pensamentos, encontramos a expressão de uma séria reserva em relação à moral dos céticos, que se contenta em seguir os costumes. ${ }^{6} \mathrm{E}$, finalmente, Pascal não deixa de defender a moral ascética dos jansenistas, seja como preâmbulo prático à fé, como no fragmento "infini-rien", seja como característica da vida do cristão, como nas cartas a Mlle. Roannez.

Para melhor evidenciar a persistência da moral como problema, um bom caminho é distinguir entre o tratamento dado à política e aquele dado à moral, por mais vizinhos que sejam os dois temas. No que diz respeito à política, Pascal defende a aceitação do poder instituído que, embora mau e injusto em si mesmo, deve ser considerado bom como instrumento de regulação da natureza decaída do homem (ou seja, é justificado pela "razão dos efeitos"). ${ }^{7} \mathrm{O}$ sentido do político se esgota na própria esfera de seu exercício e justifica-se por sua eficácia. No entanto, na esfera moral, e ao contrário do que fazem os céticos, Pascal não concede a palavra final aos costumes, dada a ausência de um critério "natural" ou universal de bem. Aqui a lógica das aparências não esgota o problema e por isto a aparência do bem será sempre perversa: o "moi" que se cobre e se transforma em "honnête homme" continua odiável, do ponto de vista da exigência da justiça. ${ }^{8}$ Em outras palavras: enquanto há uma "verdadeira moral" que "zomba da moral", não há uma "verdadeira política" para zombar da política. ${ }^{9}$ Esta é a razão pela qual, na esfera da política, soluções precárias como o governo instituído devem ser aceitas; já no que diz respeito à moral, o divertimento ou a honnêteté não podem representar soluções verdadeiras.

Colocado assim o duplo movimento pascaliano - a crítica dos sistemas morais e a afirmação de uma "verdadeira moral"-, nosso objetivo será, então, o de pensar o lugar da moral em Pascal, a partir de quatro contextos:

6 Em sua obra Penser l'irrésolution. Montaigne, Pascal et La Mothe le Vayer, Sylvia Giocanti faz um bom paralelo entre a moral dos céticos e a de Pascal (ver a Parte III).

7 La 106/403. "Buscaram-se e extraíram-se da concupiscência regras admiráveis de governo, de moral, de justiça. No fundo, porém, neste vil fundo do homem esse figmentum malum apenas se cobre. Não desaparece". (La 211/453).

8 La 597/455. 
1 - O contexto epistemológico dos fragmentos La 512/1e La513/4, qual seja, a diferença entre espírito geométrico e espírito de finesse;

2- O contexto antropológico da "desproporção do homem" e da virtude como meio-termo (La 199/72, La 800/532);

3- O contexto antropológico - teológico da miséria e grandeza do homem;

4- O contexto metafísico-teológico da teoria das "três ordens de coisas" (La 933/460).

\section{I- Moral do espírito e moral do julgamento}

Geometria. Finesse.

A verdadeira eloquiência zomba da eloqüência, a verdadeira moral zomba da moral. Quer dizer que a moral do julgamento (jugement) zomba da moral do espírito que é sem regras.

Pois é ao julgamento que pertence o sentimento, como as ciências pertencem ao espírito. A finesse é a parte do julgamento, a geometria a do espírito (La 513/4).

Moral do espírito e moral do julgamento se opõem neste fragmento, da mesma forma como o espírito de geometria se opõe ao espírito de finesse, no fragmento La 512/1. Podemos então inferir que a moral do espírito, enquanto relativa ao espírito geométrico, busca construir-se como conhecimento, raciocinando passo a passo a partir de princípios estabelecidos. Contra tal pretensão, Pascal denuncia justamente a impossibilidade de estabelecer quaisquer princípios, o que se constata através da própria diversidade de sistemas filosóficos, cada um apelando a um princípio diferente:

Por que dividiria minha moral em 4 e não em 6. Por que estabeleceria eu a virtude em 4, em 2, em 1. Porque em abstine e sustine ${ }^{10}$ mais que em seguir a natureza ou em fazer seus negócios particulares sem injustiça, como Platão, ou em outra coisa..." (La 683/20).

Ora, os sistemas morais são insuficientes e artificiais. Insuficientes não tanto porque afirmam um princípio, mas porque excluem outros:

Todos os princípios dos pirrônicos, dos estóicos, dos ateus, etc. são verdadeiros. Mas suas conclusões são falsas porque os princípios opostos são também verdadeiros" (La 619/660).

9 Sobre a política em Pascal, ver SPITZ, J.-F., 1997: "A arte de Pascal consiste então em apontar a política real como imperfeição sem reportá-la a um modelo efetivo de perfeição (...) a falsidade da ordem política não é suficiente para recusá-la, porque nenhuma outra ordem mais autêntica é possível" (p.103-104). A nosso ver, porém, esta afirmação não pode sem mais ser estendida à esfera da moral.

10 Abster-se dos bens e suportar os males: princípios estóicos. 
Artificiais, na medida em que o espírito geométrico ordena e encadeia os princípios, fazendo de uns fundamentos propriamente e de outros afirmações derivadas e consequiências, quando "a natureza estabeleceu todos, sem encerrar um no outro" (La 683/20).

Enfim, a moral do espírito é "sem regras" porque suas regras são arbitrárias, mais fruto do acaso e dos costumes que da razão. ${ }^{11}$ Mais ainda: a condição mista e terrena do homem, corpo e alma, instinto e razão, não está apta a experimentar nada de puro, nada sem ambigüidade. Daí que, mesmo se existem bons princípios, eles são inaplicáveis na prática.

Todas as boas máximas estão no mundo, só falhamos em aplicá-las (La 540/380). Cada coisa aqui é verdadeira em parte, falsa em parte. (...) Dir-se-á que é verdade que o homicídio é mau: sim, porque nós conhecemos bem o mau e o falso. Mas o que diremos que seja bom? (...) Não matar? Não, porque as desordens seriam horríveis e os maus matariam os bons. Matar? Não, porque isto destruiria a natureza. Nós não temos nem o verdadeiro nem o bem senão em parte, e misturado com o mal e o falso (La 905/385).

Pascal aqui antecipa a crítica que será feita a uma moral de tipo kantiano, ao colocar fora do alcance do homem o "bem sem restrições": se matar é sempre mau, não matar (um dos dez mandamentos) não é sempre bom. O que a moral do espírito desconhece é o conflito entre os princípios, no caso, entre a caridade e a justiça:

Eles têm alguns princípios verdadeiros, mas abusam deles; ora, o abuso das verdades deve ser punido tanto quanto a introdução da mentira. Como se houvesse dois infernos, um para os pecados contra a caridade, outro contra a justiça (La 906/916).

O trágico, porém, está em que sair de um pode significar entrar no outro...

Se a moral da lei e do mandamento não nos livra do mal, também a moral de tipo maquiavélico (ou, para falar nos termos do século XVII, a moral dos jesuítas), da prudência, do cálculo e da concessão não nos oferece uma solução melhor:

É necessário que haja desigualdade entre os homens, é verdade; mas isto concedido, eis a porta aberta não somente à mais alta dominação, mas à mais alta tirania.

Que se marquem os limites. Não há fronteiras (bornes) nas coisas. As leis querem colocá-las e o espírito não pode suportá-las (La 540/380).

11 Ver CARRAUD, V. 1992, p. 302-310. 
A necessidade de levar em conta a natureza humana e conceder algo ao mal se impõe; não temos, porém, a justa medida dessa concessão.

Diagnosticando a profunda insuficiência das soluções filosóficas, a exigência de Pascal continua sendo a de um ponto de vista que consiga afirmar todos os princípios, e que se mova dentro da própria contradição. Esta seria a característica de uma "moral do julgamento", ao modo da finesse, que consegue operar com diferentes princípios sujeitos a uma apreensão mais intuitiva que demonstrativa. ${ }^{12}$ No entanto, perguntamos, esta moral se articula positivamente em algum lugar na obra do autor dos Pensamentos? Adiemos a resposta por enquanto e continuemos nossa investigação da crítica pascaliana à moral dos filósofos.

\section{II - O contexto antropológico da "desproporção do homem" e a vir- tude como meio-termo ${ }^{13}$}

Uma das definições clássicas da virtude é a de "meio termo" entre dois extremos viciosos. Esta temática é reinterpretada pelos céticos, e de forma marcante por Montaigne, como "mediocridade" do homem, condição finita à qual ele deve adequar-se. Pascal também acentua esta característica do ser humano: somos incapazes tanto da certeza absoluta quanto de duvidar de tudo; quando se lê muito depressa ou muito devagar não se entende nada; inteligência em excesso ou a falta dela aproximam-se da loucura; barulho demasiado ensurdece e muita luz cega. ${ }^{14}$ Nossos sentidos e nossa razão não se adequam aos extremos. Pascal afirma com Montaigne: "sair do meio é sair da humanidade. A grandeza da alma humana consiste em saber circunscrever-se..." (La 518/378).

No entanto, enquanto no meio termo aristotélico ou na "mediocridade" dos céticos o que se pretende - e se alcança - é uma posição de estabilidade e de equilíbrio, o "meio" pascaliano é um lugar problemático e instável. ${ }^{15}$ No clássico fragmento sobre a "desproporção do homem", a novidade é que o meio está entre dois infinitos, e por isso, é um lugar inassinalável. Na descrição pascaliana, o meio é uma situação incômoda, nela somos empurrados de um lado para o outro. Falta-lhe a firmeza de que necessitamos:

12 “(...) os princípios são tão delicados e em tão grande número” (La 512/1).

13 Para definir este quadro de reflexão tomamos como pontos de partida a edição dos Pensamentos estabelecida por E. Martineau (PASCAL, B. Discours sur la religion et sur quelques autres sujets, 1992), principalmente os fragmentos que o editor reúne sob o título "Desproporção do homem: segundo movimento" (p. 116-118). Retomamos também em parte o artigo de CARRAUD, 1994. 
É o estado que nos é natural e, no entanto, o mais contrário à nossa inclinação. Ardemos de desejo de encontrar uma posição firme, e uma base última constante para sobre ela edificar uma torre que se eleve até o infinito; porém, os alicerces ruem e a terra se abre até os abismos (La 199/72).

Como na natureza, também na moral estamos entre dois infinitos:

A natureza parece ter feito a mesma coisa através de seus dois infinitos naturais e morais. Sempre teremos um acima e um abaixo, os mais hábeis e os menos hábeis, os mais elevados e os mais miseráveis, para rebaixar nosso orgulho e elevar nossa abjeção (La 800/532).

De modo que não há repouso possível, nem no orgulho, nem na consciência da miséria - como o julgam erradamente os filósofos - porque entre dois infinitos o que não há é o meio termo. ${ }^{16}$

Há ainda uma dificuldade extra para se assinalar o meio termo na moral: de qualquer forma, é possível indicar os sons audíveis entre o silêncio e o barulho ensurdecedor, e também o ponto de perspectiva para a admiração dos quadros; no entanto, "na verdade e na moral, quem o assinalará?" (La 21/ 381). O costume, que o faz, é mais afastado da natureza e do instinto que o ouvido ou os olhos.

Pensamos que o meio-termo ou o ponto de equilíbrio é impossível na moral porque, ao contrário do que ocorre na política, aqui existe um modelo que é o oposto da mediania: Jesus Cristo. Desta perspectiva, que é a do infinito, não pode haver um excesso na bondade, nem na justiça. Como assinala Carraud: "o excesso de uma virtude é ainda virtude"17, e o que Pascal exige é que se exceda em virtudes opostas, como a coragem e a bondade (La 681/ 353). No entanto, nossa condição de seres medianos não o permite: "Quando se quer perseguir as virtudes até os extremos de uma parte e de outra, apresentam-se os vícios (...) do lado do pequeno infinito (...) e do grande infinito (...)" (La 783/357). Como vimos, na experiência humana a extrema bondade é o mínimo de justiça, a extrema castidade é o fim da espécie, etc.

Assim, a verdadeira moral, a moral do julgamento, reinterpreta a moral do meio-termo: se a mediania é nossa condição, ela é inteiramente problemática, pois é necessário afirmar também o princípio oposto, a virtude como extremo (Cristo como extrema bondade e extrema justiça). Pascal dissocia virtude e meio-termo, com isto mostra a impossibilidade da virtude para nós. A moral constitui-se enfim como necessidade de oscilar continuamente entre o orgulho e a miséria: "Se ele se vangloria eu o rebaixo. E o contradigo

14 La 21/381, La 199/72.

15 Para uma leitura diferente, que afirma a instabilidade na ética cética, ver GIOCANTI, 2001, p. 632 ss.

16 Pascal "põe fim ao paradigma aristotélico que repousava sobre a equidistância dos extremos" (CARRAUD, 1994, p.683).

17 Idem, p. 684. Retomo o problema de Carraud, afastando-me porém de sua interpretação. 
sempre, até que ele compreenda que é um monstro incompreensível" (La 130/420).

\section{III- O contexto antropológico — teológico da miséria e grandeza do homem}

Podemos pensar que a "moral do espírito", alvo das zombarias de Pascal, pode ser dita do "espírito" não apenas em seu método, mas também em seu conteúdo. Neste caso, a moral do espírito é aquela que acredita no homem como ser essencialmente racional. $\mathrm{O}$ autor dos Pensamentos mobiliza toda uma fina análise psicológica para atacar esta antropologia, atingindo em seu âmago, desta vez, a idéia da razão como o mais próprio do homem, sua virtude ou excelência. A estratégia pascaliana é mostrar que, por trás dos gestos considerados nobres (porque guiados pela razão, faculdade autônoma), revelam-se suas verdadeiras motivações, de forma que as ditas virtudes sempre escondem algo, elas são uma máscara. Mais ainda: o que se esconde, sempre, sob o manto da virtude é a tirânica busca do prazer. Especialmente contra a moral estóica, que afirma uma esfera da vontade reinando acima da dos instintos, Pascal mostra que só se recusam os prazeres corporais em nome dos prazeres espirituais (afirmação do poder, vaidade, glória), não raro mais perversos que os primeiros:

Ele (o homem) é agora escravo do deleite; o que mais o deleita o atrai infalivelmente(...) e que não se pretenda usar de sutilezas, dizendo que a vontade, para marcar seu poder, escolherá algumas vezes o que lhe agradar menos; porque então ela tem mais prazer em mostrar o seu poder que no bem que ela deixa .... ${ }^{18}$

Como veremos adiante, toda a experiência humana pode ser descrita sob o tema das concupiscências: a da carne, a do espírito e a da vontade. Além disso, o império do deleite está presente mesmo nas virtudes cristãs, como a piedade: "Lamentar os desgraçados não é contra a concupiscência. Ao contrário, bem satisfeitos ficamos ao render este preito de amizade e angariar uma reputação de ternura sem nada dar em troca" (La 657/452).

Podemos neste ponto aproximar a moral pascaliana da de Hobbes, cujo fundamento está no desejo ou aversão. Se não temos em Pascal um materialismo metafísico como em Hobbes, temos, no entanto, em oposição à "moral do espírito", uma espécie "moral dos instintos", que remete a dinâmica da alma à dinâmica do corpo. Corpo, vontade e razão são regidos pelo princípio 
do prazer. ${ }^{19}$ Esta "moral dos instintos" oposta à "moral do espírito" é também uma moral racionalista, pois usa a razão como instrumento crítico das ilusões do homem sobre si mesmo e compreende a natureza humana a partir de uma espécie de inapelável mecânica das paixões. Às vezes a virtude pode ser, apenas, o efeito do equilíbrio de dois vícios contrários, uma simples resultante de forças, sem nenhum mérito ou substância real. ${ }^{20}$

Razão e vontade humanas são, integralmente, partes da natureza e seguem a mesma lógica desta. Nem mesmo a graça transfigura esta realidade: "não se deixam os prazeres, senão por outros maiores", escreve Pascal aos Roannez, citando Tertuliano. ${ }^{21}$

A virtude é, na acepção clássica, o domínio das paixões por um outro que não elas mesmas (a razão); já na antropologia de Pascal não há este outro, uma paixão só podendo se anular na presença de outra paixão. Enfim, a virtude não é o que parece, e aqui não estamos tão longe de Maquiavel. Daí que o "eu" será, não a vontade ou a razão, como para os filósofos, nem mesmo a alma que pensa, como em Descartes, mas uma grande figura do instinto: o amor-próprio.

Esta moral pascaliana sem dúvida "se ri" da moral da excelência, e do homem virtuoso tão iludido sobre si mesmo. Mais realista, ela é também mais verdadeira: a hermenêutica do desejo mostra a miséria do homem. No entanto, esta não é a última palavra de Pascal sobre o desejo, nem sobre a moral, porque a própria realidade do desejo leva-nos a uma outra verdade, à grandeza do homem, e em dois sentidos: primeiro, como consciência da miséria; segundo, como marca de uma origem divina.

Quanto ao primeiro sentido, Pascal aqui recupera a tradição do conhecimento de si como fundamento da moral. Assim como a consciência da ignorância em Sócrates, também no pensador moderno a consciência de si é o que marca a vida humana e lhe confere sua dignidade:

O homem não passa de um caniço, o mais fraco da natureza, mas é um caniço pensante. Não é preciso que o universo inteiro se arme para esmagá-lo; um vapor, uma gota d'água são suficientes para matá-lo. Mas, mesmo que o universo o esmagasse, o homem seria ainda mais nobre do que quem o mata, pois ele sabe que morre e da vantagem que o universo tem sobre ele. O universo não sabe nada disso.

Toda nossa dignidade consiste então no pensamento (...). Trabalhemos então para bem pensar: eis o princípio da moral (La 200/348).

19 Ver o artigo "L'amour selon Pascal" de André Comte-Sponville, 1997.

20 La 674/359. Sobre este ponto, ver o acima citado artigo de CARRAUD, 1994, que se refere a uma "virtude sem sujeito virtuoso" (p. 683).

21 Lettres aux Roannez (p. 269, Ed. Lafuma). A este propósito, escreve Bénichou: "O coração humano, amando a Deus, não muda de natureza. Seu deleite mudou de objeto pela graça de Deus, mas permanece deleite bruto (...)" (p. 126). Ver também La 269/692. 
Como em Sócrates e nos estóicos, também em Pascal a grandeza do homem consiste no saber de si mesmo, e nisto ele é superior ao universo. Ao contrário dos estóicos, porém, a consciência de si é consciência da finitude e da fraqueza e, para além de Sócrates, é consciência da miséria. ${ }^{22}$ Saber-se miserável é saber-se lugar de um desejo infinito e impossível de ser realizado: "Nós somos incapazes de não desejar a verdade e a felicidade, e somos incapazes da certeza e da felicidade" (La 401/437). Um impasse se cria, então, no cerne da moral: se "bem pensar" é o seu princípio, não podemos ter, seguindo este caminho, sua realização, pois a consciência da miséria (associada por nosso filósofo ao realismo dos céticos) só é capaz de levar ao desespero. A alegria da moral zombeteira, que revela as misérias do homem, dura muito pouco, pois é uma zombaria desesperada. Ao invés de atingir o fim de toda moral, a felicidade, o conhecimento de si gera o tédio e a infelicidade; é insuportável ficar diante de si mesmo (La 622/131). Por isto o "divertimento" se justifica, e o autor dos Pensamentos não hesita em afirmar que "é melhor se ignorar para ser feliz" (La 687/144). Aqui há uma disjunção entre consciência (grandeza), por um lado, e felicidade, por outro.

Ora, se a moral do julgamento não pode abrir mão do "conhece-te a ti mesmo" como um princípio, ela também não pode abrir mão do princípio oposto, a felicidade. De modo que a verdadeira moral exige, para além da filosofia cética, um segundo sentido de grandeza, uma grandeza que seja mais que a mera consciência da miséria ${ }^{23}$, e portanto capaz de contrabalançar o desespero. No entanto, tal exigência só poderá ser preenchida no horizonte da revelação cristã. Sabemos que um dos argumentos centrais da apologética de Pascal é que o cristianismo fornece a chave para interpretar o desejo como sinal e marca de uma história que situa o homem para além de si mesmo. Em outras palavras, a realidade do desejo ${ }^{24}$ aponta não só para a miséria, mas também para uma origem divina do homem:

(...) O que nos gritam esta avidez e esta impotência senão que houve outrora no homem uma verdadeira felicidade, da qual não lhe resta agora senão a marca e o traço vazio que ele tenta inutilmente preencher (...) (La 148/425).

A "verdadeira moral" só se realiza uma vez que se saia do domínio da filosofia para o da revelação: a grandeza do homem só se compreende plenamente no horizonte da história da criação e da queda, na afirmação de uma

22 La 114/397.

23 Neste ponto nos afastamos da interpretação de Bénichou, p. 120.

24 Importante ressaltar aqui que é o desejo infinito, e não a razão ou a consciência propriamente, a marca do divino no homem. 
primeira natureza para além da natureza decaída, pela qual "o homem ultrapassa o homem" (La 131/434). O desejo é marca de uma origem divina e só pode encontrar seu preenchimento se assistido pela graça. Só assim a moral pode ir além do desespero em direção à esperança: “Toda a moral consiste na concupiscência e na graça" (La 226/523).

\section{IV- Moral e caridade no contexto das três ordens. ${ }^{25}$}

Retomando uma passagem de São João ${ }^{26}$, Pascal refere-se no fragmento La 933/460 a três ordens de coisas: a carne, que diz respeito ao desejo das riquezas e do poder sobre as coisas; o espírito, relativo ao desejo de conhecimento e à curiosidade; e a vontade, que é o desejo de sabedoria e de justiça, enfim da virtude. ${ }^{27}$

Embora não esteja explícito no texto, evidentemente a moral se situaria na terceira ordem. A sabedoria, diferente do conhecimento, é propriamente o poder de julgar sobre o bem e o mal e de viver segundo este julgamento; ela é o próprio exercício da vontade enquanto domínio sobre si mesma. Pascal tem presente aqui a concepção estóica da vontade como poder sobre si mesma, como capacidade de autodeterminação; a vontade que é, enfim, o divino no homem. Nesta perspectiva, o exercício pleno da vontade é o lugar do maior deleite do homem, que se compraz em si mesmo. A vontade se fecha em si, ela é seu próprio fim.

$\mathrm{Na}$ leitura pascaliana, esta moral não passa de uma forma de concupiscência: a da posse de si e do deleite em si. $^{28}$ Do ponto de vista humano, da moral do espírito, ela é a ordem mais alta, tanto que Pascal concede-lhe o orgulho legítimo ("não podemos aceitar que um homem que se tornou sábio esteja errado ao considerar-se glorioso, porque isto é justo"). No entanto, a moral do julgamento denuncia que há males travestidos de bens:

O mal é fácil e há uma infinidade de males; o bem é quase único. Mas um certo gênero de mal é tão difícil de encontrar quanto aquilo a que se chama bem. E muitas vezes faz-se passar por bem este mal particular. É mesmo necessária uma grandeza de alma extraordinária para alcançá-lo tanto quanto o bem (La 526/408).

25 A referência básica sobre este ponto é o artigo de MESNARD, 1992. Ver também Revue de Métaphysique et de Morale, volume 1/ 1997, intitulado Les trois ordres de Pascal.

26 I João 2:16: "Porque tudo o que há no mundo, a concupiscência da carne, a concupiscência dos olhos e a soberba da vida, não procede do Pai, mas procede do mundo".

27 No mesmo sentido temos o fr. La 433/783: "Tudo que há de grande sobre a terra se une [contra Deus]: os cientistas, os sábios, os reis. Uns escrevem, os outros condenam, os outros matam".

28 Embora literalmente a palavra concupiscência não apareça associada à vontade, o contexto autoriza aproximá-la da "concupiscência da carne" e da "concupiscência dos olhos". A associação virtude-prazer já aparece em Montaigne: ver o ensaio "Da Crueldade". 
A grandeza da alma, o maior dos bens na perspectiva dos filósofos, se converte no maior dos males na perspectiva de Pascal, e da moral do julgamento. A "verdadeira moral" apresenta-se como o reverso da moral dos filósofos, contra o orgulho: "aquele que se gloria, glorie-se no Senhor", conclui Pascal citando São Paulo ao final do fragmento 933.

O tema das três ordens está também no fragmento La 308/793, mas de uma outra maneira: aqui, a "distância infinita" entre corpo e espírito é uma figura da distância "infinitamente mais infinita" entre espírito e caridade. A vontade não aparece na terceira ordem, e ocupando o seu lugar temos a caridade. Além disso, enquanto no fragmento La 933 as três ordens são concupiscências que se opõem a Deus, no fragmento La 308 a caridade opõe-se às outras duas ordens enquanto ordem divina. E, finalmente, em um, o modelo moral é o sábio estóico que se orgulha de si, em outro o modelo é a humildade de Cristo.

A substituição da vontade pela caridade nos leva a pensar que, entre a moral dos filósofos e a caridade, o que ocorre não é apenas uma mudança do objeto da vontade ${ }^{29}$ - do amor ao mundo ou às ciências ao amor a Deus mas que a conversão da vontade significa afinal uma transformação de sua própria natureza. A vontade deve deixar de ser, deixar de querer-se a si mesma. A caridade é neste sentido a negação da vontade; ela não é a vontade como força se exercendo em uma outra direção, mas toma o próprio lugar da vontade. O objetivo não é deleitar-se no sacrifício como afirmação da força da vontade, mas que este sacrifício seja o de si mesmo e o da vontade. Enquanto desejo de seu próprio exercício, a vontade é a forma mais acabada do amor de si: "A natureza do amor próprio e do 'eu' humano é a de não amar senão a si e de não considerar senão a si" (La 978/100). ${ }^{30}$ Assim, ela se opõe radicalmente à caridade, na mesma ordem. ${ }^{31}$ Na moral do julgamento, a vontade renuncia-se a si mesma" e "consente na do ser universal" (La 360/482). A virtude deixa de ser excelência para tornar-se humildade.

Esta é a exigência da "verdadeira moral": que a vontade dê lugar à caridade. Prova disso é que a oposição caridade/corpo e caridade/espírito é diferente da oposição caridade/vontade. A vida do cristão, na caridade, não abstrai do corpo ou do espírito, pelo contrário, é preciso conviver com o

29 Fato assinalado por Mesnard: "A ordem da vontade é, mais fudamentalmente, aquela do 'coração', daquela potência de amar que se volta, seja para as criaturas, seja para o Criador, seja para o "eu", seja para Deus. Ele inclui então toda uma parte de afetividade, na qual a vontade, faculdade de decisão, mergulha suas raízes" (p. 470).

30 La 617/492. A justiça exige que se esvazie o eu do amor próprio que o define.

31 Lemos no citado artigo de Mesnard: "o amor próprio permanece fundamentalmente um amor e como tal, pertence sempre à 3a. ordem" (p. 479).

32 La 362/249. 
corpo e com o espírito como com vizinhos, às vezes em conflito, mas ocupando cada um o seu lugar. Trata-se sobretudo de estabelecer os limites de direito de cada ordem, evitando assim a tirania, definida como "querer ter por uma via o que só se pode ter por outra", e de dar a cada uma a sua parte: "dever de amor ao agrado, dever de temor à força, dever de crença às ciências" (La 58/332). Do lado do corpo, sabemos o quanto sua disciplina predispõe à caridade (La 418/233), que quem quer ser anjo torna-se besta (La 678/ 358), e que o costume é também um modo de crer (La 808/245). Do lado do espírito, a razão e a argumentação têm seu lugar no caminho para a fé, e todo o projeto de uma Apologia é prova disso.

Portanto, o que a caridade pede é o "esvaziamento do eu", do "eu" que se faz centro de tudo. Chegando a este ponto porém, a caridade não seria a negação de toda moral enquanto negação da vontade e do sujeito? E ainda: não é o próprio Pascal que afirma que é impossível negar o amor de si, a busca do deleite? ${ }^{33}$

Para esclarecer esta questão, recorremos ao conjunto de fragmentos sobre a relação entre corpo e membros, que sem dúvida referem-se à "verdadeira moral". ${ }^{34}$ Aqui exige-se "regrar o amor que se deve a si mesmo" (La 368/ 474), amando-se como membro do corpo, não como centro de tudo, e "submeter a vontade particular à vontade primeira que governa o corpo inteiro" (La 374/475). A "verdadeira moral" se apresenta como a moral dos "membros pensantes", do corpo, figura da Igreja, e não como moral do "eu". ${ }^{35}$

Ora, "amando o corpo ele [o membro] se ama a si mesmo porque não tem ser senão nele e por ele" (La 372/483). Ao modo do espírito de finesse, esta moral afirma dois princípios opostos, o amor de si (como parte) e o amor do corpo (o todo). Por um lado, o amor de si continua operante, pois a moral da caridade ainda diz respeito ao eu e à sua felicidade; não saímos do registro do deleite. Por outro lado, esta felicidade se realiza através da inclusão do Outro e dos outros em sua dinâmica. A negação de si é afirmação de si no corpo; o amor de si é amor do outro. A moral do sentimento tem que articular princípios contraditórios, tem que dar conta do amor de si (pois este é inalienável) e do amor do outro (como exigência moral), amando-se enquanto parte de um todo. Tornar-se parte, porém, deixando de ser o "eu" vazio que se faz centro de tudo, já é, em si, uma experiência que exige o horizonte da graça.

33 "Ele não poderia por sua natureza amar outra coisa senão para si mesmo e para servir-se dela, porque cada coisa se ama acima de tudo" (La 372/483).

34 Papiers Classés XXVI da Edição Lafuma, sob o título Moral Cristã (La 351-376).

35 Ver La 360/482. 
Cumpre notar ainda que, enquanto forma de amor, a caridade abre-se para o Outro não como seu objeto, mas como seu princípio. Se assim não fosse não haveria possibilidade de afirmar ao mesmo tempo o amor de si e o amor de Deus, e o homem ficaria dilacerado entre ambos. No entanto, a caridade pode afirmar os dois princípios (amor de si e amor de Deus) porque ela não começa com o homem, mas com Deus, porque "amar a Deus é antes ser amado por ele". ${ }^{36}$ Não se trata de amar isto ou aquilo, mas de reconhecer-se amado. O eu se esvazia como fonte absoluta do amor, o amor a Deus é o amor de Deus. Esta afirmação, condição da moral, só pode ser feita no horizonte da revelação, e não mais no horizonte da filosofia. Assim, como a antropologia do Entretien, a "verdadeira moral" deixa o campo da filosofia para adentrar-se na teologia.

\section{Conclusão: "Toda a moral [consiste] na concupiscência e na graça" (La 226).}

Retomando o que foi dito até aqui, concluiremos traçando um perfil da "moral do julgamento" ou "do sentimento".

Esta moral articula dois discursos: o da concupiscência e o da graça. Do lado do discurso sobre a concupiscência, encontramos em Pascal uma perspectiva naturalista, que ressoa Montaigne, mas que encontra seu melhor paralelo em Hobbes. Este discurso dissolvente constitui, em alguma medida, uma moral verdadeira, pois é mais realista, mais atento aos movimentos da alma que a filosofia ao modo dos estóicos. Pascal pratica aqui uma espécie de "filosofia da suspeita", que desmascara as virtudes e revela a natureza precária do homem, primeiro ensinamento moral de importância.

Se este discurso que desvela a miséria do homem fosse a última palavra de Pascal, o homem seria definitivamente retirado da esfera moral para tornar-se escravo dos instintos, da imaginação, para ancorar-se de vez na natureza. Ou, para colocar a questão em outros termos, teríamos em Pascal uma moral como mera expressão da natureza, cujos termos grandiosos encobrem apenas uma má compreensão antropológica.

No entanto, a última palavra do autor dos Pensamentos sobre o homem não é miséria, mas desejo. Tomado em si mesmo, e não pelo viés de seus fracassos, o desejo é sinal de uma natureza perdida, de uma grandeza do homem. O ponto essencial é que o amor-de-si, desejo primeiro e origem de todo mal, pode ser transfigurado e interpretado como amor de Deus que se 
desviou. Esta compreensão do desejo, no entanto, só é possível a partir da perspectiva da graça ou da revelação, e é ela que faz com que a moral que zomba da moral ainda seja uma moral, quer dizer, recupere e dê nova significação às exigências morais da filosofia.

Em síntese, os dois registros da moral de Pascal permitem afirmar, ao mesmo tempo, que:

1-a virtude não é mais que a máscara do vício (redução à natureza, à concupiscência),

2- os vícios, e mesmo o maior deles, o amor de si, são uma forma desviada do amor (interpretação no horizonte da graça).

A decifração de Pascal tem dois sentidos, sempre: vai das pretensas virtudes ao amor de si, à concupiscência radical que elas encobrem, mas vai também do amor de si ao amor de Deus que se perdeu. Em seu primeiro movimento, a moral pascaliana é simplesmente naturalista e, digamos assim, científica. Em seu segundo movimento ela é teológica, pois só a afirmação de Deus e do amor de Deus é capaz de decifrar o desejo como amor, no sentido de caridade.

Estes dois discursos constituem a "verdadeira moral", a moral do espírito de finesse, capaz de abarcar em si concupiscência e graça. Não há como se instalar em apenas um deles: o primeiro exige o segundo, pois a maior prova da razoabilidade da razão é reconhecer seus limites, e o segundo não é capaz de "superar" o primeiro, pelo menos na vida terrena, onde Deus é um Deus escondido. Se na política as máscaras não cobrem nada, e justificam-se por sua eficácia no mundo decaído, a moral é em si mesma uma máscara que, dependendo da perspectiva, ou esconde a concupiscência, ou esconde Deus. Por isto é necessário "bem pensar", operando ambos os princípios, pois não há repouso possível.

\section{BIBLIOGRAFIA}

BÉNICHOU, P. Morales du grand siècle. Paris, Gallimard, 1948.

CARRAUD, V. Pascal et la philosophie. Paris: PUF, 1992.

"Le deux infinis moraux et le bon usage des passions. Pascal et les passions de l'âme". XVII siècle, no. 185, 1994, (p. 669-694).

COMTE-SPONVILLE, A. "L'amour selon Pascal". Revue Internationale de Philosophie. no. 199, 1997/1, p. 131-160.

GIOCANTI, S. Penser l'irresolution. Montaigne, Pascal et La Mothe le Vayer. Paris, Honoré-Champion, 2001.

MESNARD, J. "Le thème des trois ordres dans l'organization des Pensées", in La culture du XVIIème. siècle. Paris, PUF, 1992. 
MONTAIGNE, M. Les Essais. (Ed. Pierre Villey). Paris: PUF, 1988.

PASCAL, B. Oeuvres Complètes. (Ed. Louis Lafuma). Paris: Ed. du Seuil, 1963. Discours sur la religion et sur quelques autres sujets (Restitués et publiés par Emmanuel Martineau). Paris: Fayard, Armand Colin, 1992.

Pensamentos (tradução de Sérgio Milliet a partir da Edição de Brunschvicg). São Paulo, Abril Cultural, 1973.

PÉCHERMAN, Martine. "L'ordre dans les trois ordres et l'ordre des trois ordres chez Pascal" in Revue de Métaphysique et de Morale, 1997/1, p. 19-40.

SPITZ, J.-F. “Apparence et fausseté: La double nature de l'ordre politique chez Pascal.” Revue Internationale de Philosophie, no. 199, 1997/1, p. 100-118. 